\title{
Design and Construction of a Cold Room with Photovoltaic Support for Lighting
}

\author{
Ricardo Fabricio Muñoz Farfán \\ Instituto Superior Tecnológico Paulo Emilio Macías, Portoviejo, Manabí \\ Corresponding author email: itspem.rmunoz@gmail.com \\ Telly Yarita Macías Zambrano \\ Instituto Superior Tecnológico Paulo Emilio Macías, Portoviejo, Manabí \\ Email: itspem.rmunoz@gmail.com

\section{Victor Manuel Delgado Sosa} \\ Instituto Superior Tecnológico Paulo Emilio Macías, Portoviejo, Manabí \\ Email: itspem.jmenendez@gmail.com \\ Jorge Daniel Menéndez López \\ Instituto Superior Tecnológico Paulo Emilio Macías, Portoviejo, Manabí \\ Email: itspem.gramas@gmail.com \\ Germán Temístocles Ramos León \\ Instituto Superior Tecnológico Paulo Emilio Macías, Portoviejo, Manabí \\ Email: itspem.gramas@gmail.com
}

\begin{abstract}
One of the problems encountered today is the inefficiency of refrigeration systems and electrical equipment. The present study proposes the manufacture of a refrigeration chamber that responds to a great variety of needs both in industrial processes, medicine, and domestic service, becoming an indispensable process within the socio-productive sector. The proposed system has an investigative scope, as a contribution to the agricultural food sector for the derivation of variables and the behavior of products (plants-food) and its method of conservation for quality towards the consumer. The type of investigation responds to the experimentation supported by an observation card with variable rate testing tests. Given the aforementioned, a freezing and refrigeration system is elaborated, taking advantage and optimizing an air conditioning system that works up to $24^{\circ} \mathrm{C}$ in the room and under the modification obtain temperatures of $-15^{\circ} \mathrm{C}$, starting from an average temperature of $29^{\circ} \mathrm{C}$ and a $65 \%$ relative humidity of the outside. For the selection of the equipment, the installed capacity of 1.5 tons of cold was considered with an average consumption of 6 amperes/hour, $R 22$ refrigerant gas $(S A, 2009)$ and for its verification, an electronic controller TH2O (RCA) was used; As a product, water is used, reaching freezing after 20 minutes of operation of the equipment.
\end{abstract}

Keywords---freezing, installed capacity, photovoltaic panel, $R-22$ gas, temperature, TH20 roller.

\section{Introduction}

Refrigeration is a process that consists of reducing or maintaining the temperature according to the products being treated, spaces, or even materials concerning the temperature of the environment around them. At present, refrigeration has a wide variety of applications and is involved in a series of industrial processes ranging from the food sector, chemistry, medicine, and even in the treatment of metals. This research is part of a research process that began with the design and construction of a conditioning system for industrial buildings (Muñozet al., 2020). 
Refrigeration by mechanical compression (Quinto et al., 2005), is responsible for removing the energy from the hot sink where the products are stored, that is, its objective is to control the temperature according to the needs of preserve food in stable conditions for marketing.

At the territorial level Ecuador, along with its coastal profile, its agricultural production is based on fishing with $60 \%$, which leads to the manufacture of cold rooms for conservation and commercialization both for large producers and retailers, being the Manta canton, from the province of Manabí, the tuna exporter in the first order at the regional level, the majority commercialized in the United States, Europe, and Asia (FAO, 2017). Given the aforementioned, Ecuador is an important global player in the tuna industry. In the eastern Pacific Ocean, it has the largest purse seine fleet, main catch, and the largest processing capacity. The highest number of one is exported processed (cans and bags) or as precooked tuna loins for the second transformation (Rehman et al., 2017; Gooding et al., 2013). The main tuna stocks are close to maximum yield, there are significant concerns regarding the overcapacity of the fishing fleet and the impact of some fishing techniques on the stocks of tuna and other marine species (eg sharks).

Dorado fishing represents around 65\% of large pelagic fish landings and is the main export product of white fish $(40 \%)$ (Ministry of Aquaculture and Fisheries, 2014). Given the aforementioned, it is essential to meet local needs, national and regional at a global level in the field of food preservation in order of production such as meat products, flowers, chemicals, and health; guaranteeing quality and reliability at the service of society.

In the study base, guidelines are established such as the materials of the chamber, including expanded polyethylene, resin polymer plates, iron, and adjustment elements for their fixation (Gónzalez de la Cruz \& Gónzalez, 2006). Information was sought related to the use of photovoltaic solar panels in cooling (Bravo et al., 2018; Nižetić et al., 2016), and information was sought on $15 \mathrm{~W}$ panels (Solar, 2021), controller, battery, pilot lights.

The photovoltaic system will make it possible to take advantage of the solar energy that can be obtained in the area, mainly in the coastal of the province of Manabí (Rodríguez \& Vázquez, 2018; El Mays et al., 2017), where radiation levels are very high and can be active for different uses. The implementation of the use of renewable energy sources helps to achieve sustainable energy development (Pérez et al., 2020). The objective of the research is to design a refrigeration system that can be operated under special conditions and that the lighting inside the chamber is carried out with the operation of a photovoltaic system.

\section{Materials and Methods}

This research was developed in the city of Portoviejo - Manabí - Ecuador position $341^{\circ} \mathrm{N}, 170 \mathrm{ft}$ height, 1 atm. Atmospheric pressure; at the facilities of the Paulo Emilio Macías Higher Technological Institute, with an experimental design based on several testing tests at variable rate interval, applied to a refrigeration system, proposed as an eco-sustainable technology transfer alternative that is intended to be achieved from ambient temperatures of $30^{\circ} \mathrm{C}$ to $-2^{\circ} \mathrm{C}$.

\section{Results and Discussions}

The alternative of improving efficiency and starting with the path of sustainability and use of indigenous resources (Gámez et al., 2019), decreasing environmental impacts. The design of a cooling system has started. For its construction, different materials and equipment have been used that will allow it to materialize as an industrial and commercial conditioning system already in operation. Some materials and equipment that were used for construction are listed, for example, the mechanical cold equipment, photovoltaic system, pipes of different dimensions, contactor, pilot lights, controller, refrigerant gas, expanded polystyrene, sealing rubber with a magnet, angles of different dimensions, electrodes, tubes, among other materials.

\section{Description of the refrigeration system}

This prototype is part of the process of reuse or recycling of elements, materials, or components that are out of operation, helping to reduce environmental pollution due to the manufacturing factor of new products, it uses electronic control to optimize the operation and improve efficiency (Real Pérez, 2017), for the internal lighting of the

cold chamber a photovoltaic system was incorporated, to supply the electric current thereby reducing consumption energy and therefore reduce environmental impacts achieving sustainability over time. In figure 1 the cold room is shown and in figure 2 the control system of the room. 


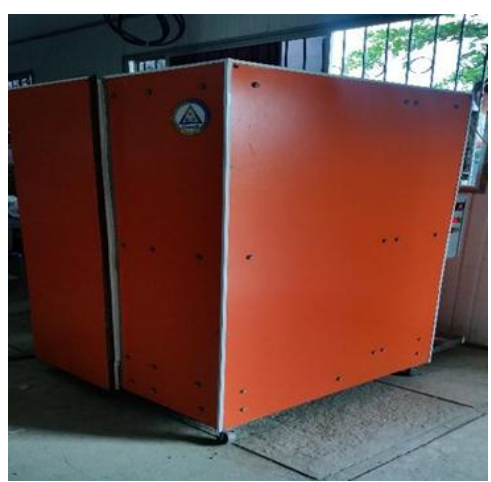

Figure 1. Cold room

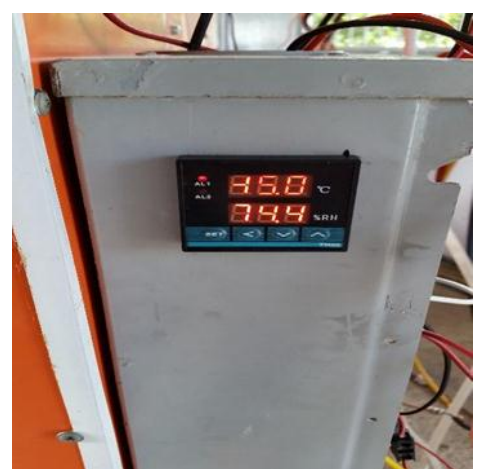

Figure 2. Room control system

The cold room has an installed cold capacity of $12000 \mathrm{Btu} / \mathrm{hr}$, with its equivalents of $3330 \mathrm{Kcal} / \mathrm{hr}$, under the work of a mechanical compression system at the dry regime. The humidity and temperature sensor system, as well as the machine on and off, will be in charge of the TH -20 controller to achieve the best performance of the equipment where refrigeration and freezing temperatures can be obtained. automating processes according to the demand of the products in conservation. The mentioned controller works with two capacitive type sensors, which react to metals and non-metals, framed by the connection distance depending on the material, being greater when the dielectric constant is higher (TURCK, 2020), its installation will be in the evaporator unit, and the humidity sensor in the center of the cold room (Logicbus, 2020).

The cold chamber has a volume of $9.36 \mathrm{~m} 3$ with a capacity of preservation products of approximately $250 \mathrm{Kg}$, the walls are made of insulating materials for heat transfer such as expanded polyethylene $\mathrm{K}=0.035 \mathrm{~W} / \mathrm{m}^{\circ} \mathrm{K}$, polymer sheets of resin with a coefficient $\mathrm{K}=0.12 \mathrm{~W} / \mathrm{m}^{\circ} \mathrm{K}$. (Syrek et al., 2020; Oh \& Son, 2011; Cho \& Tae, 2001) on both surfaces with a thickness of 0.05 meters. The internal lighting system of the chamber is made using a photovoltaic system that satisfies an energy demand of $10 \mathrm{~W} /$ hours, under the light-emitting diode system, being a sustainable lighting system. Table 1 shows the technical characteristics of the photovoltaic solar panel.

Table 1

Technical characteristics of the Photovoltaic Solar Panel

\begin{tabular}{ll}
\hline Description & Quantity \\
\hline Output voltage & $18 \mathrm{Vdc}$. \\
Maximum output current & $0.83 \mathrm{~A}$. \\
Power & $15 \mathrm{Watts}$ \\
Open circuit voltage & $22 \mathrm{~V}$. \\
Short circuit current & $0.9 \mathrm{~A}$. \\
Dimensions of the Solar Panel & $39 \times 36 \times 2(\mathrm{~cm})$ \\
\hline
\end{tabular}


Verification process

The data verification process expected by the cold production equipment is carried out in the Laboratory Workshop of conditioning systems and refrigeration from the Paulo Emilio Macías Higher Technological Institute, with data from variable measurements. The measuring instrument used a TH-20 temperature and humidity controller, with the following characteristics shown in table 2 the technical data of the TH 20 series controller.

Table 2

Technical characteristics of the temperature and humidity controller

\begin{tabular}{ll}
\hline Description & Quantity \\
\hline Contact Capacity & 10 amp $/ 250 \mathrm{~V}$ \\
Control & $-40{ }^{\circ} \mathrm{C} \sim 80.0^{\circ} \mathrm{C}$ \\
TemperatureTemperature & $0.0 \sim 99.9 \% \mathrm{RH} \% \mathrm{RH}$ \\
Operating & 10 to 100 (No Condensation \\
HumidityHumidity & $+/-0.5^{\circ} \mathrm{C},+/-3 \%$ RH \\
Measurement Accuracy & \\
\hline
\end{tabular}

Source: Research Group

Technical Operating Parameters System

Table 3 shows the data and freezing chamber sampling freezing chamber

Table 3

Sample

\begin{tabular}{llll}
\hline Test & $\begin{array}{l}\text { No. Internal vacuum } \\
\text { chamber temperature }\left({ }^{\circ} \mathrm{C}\right)\end{array}$ & $\begin{array}{l}\text { Equipment operating time } \\
(\text { minutes between on and off) }\end{array}$ & $\begin{array}{l}\text { Operating time } \\
\text { min. }\end{array}$ \\
\hline 1 & 24 & 0 & 0 \\
2 & 18 & 1.2 & 1.2 \\
3 & 15 & 1.35 & 2.55 \\
4 & 12 & 1.2 & 3.75 \\
5 & 10 & 1 & 4.75 \\
6 & 8 & 0.95 & 5.7 \\
7 & 6 & 0.88 & 6.58 \\
8 & 4 & 0.7 & 7.28 \\
9 & 1 & 0.7 & 7.98 \\
10 & -2 & 0.71 & 8.69 \\
11 & -4 & 0.73 & 9.42 \\
12 & -6 & 0.74 & 10.16 \\
13 & -8 & 0.76 & 10.92 \\
14 & -10 & 0.72 & 11.64 \\
15 & -13 & 0.95 & 12.59 \\
16 & -15 & 0.9 & 13.49 \\
17 & -18 & 0.99 & 14.48 \\
18 & -20 & 1 & 15.48 \\
\hline
\end{tabular}


Analysis of team results of freezing

In figure 3, the correlation of temperature concerning the number of samples taken is shown.

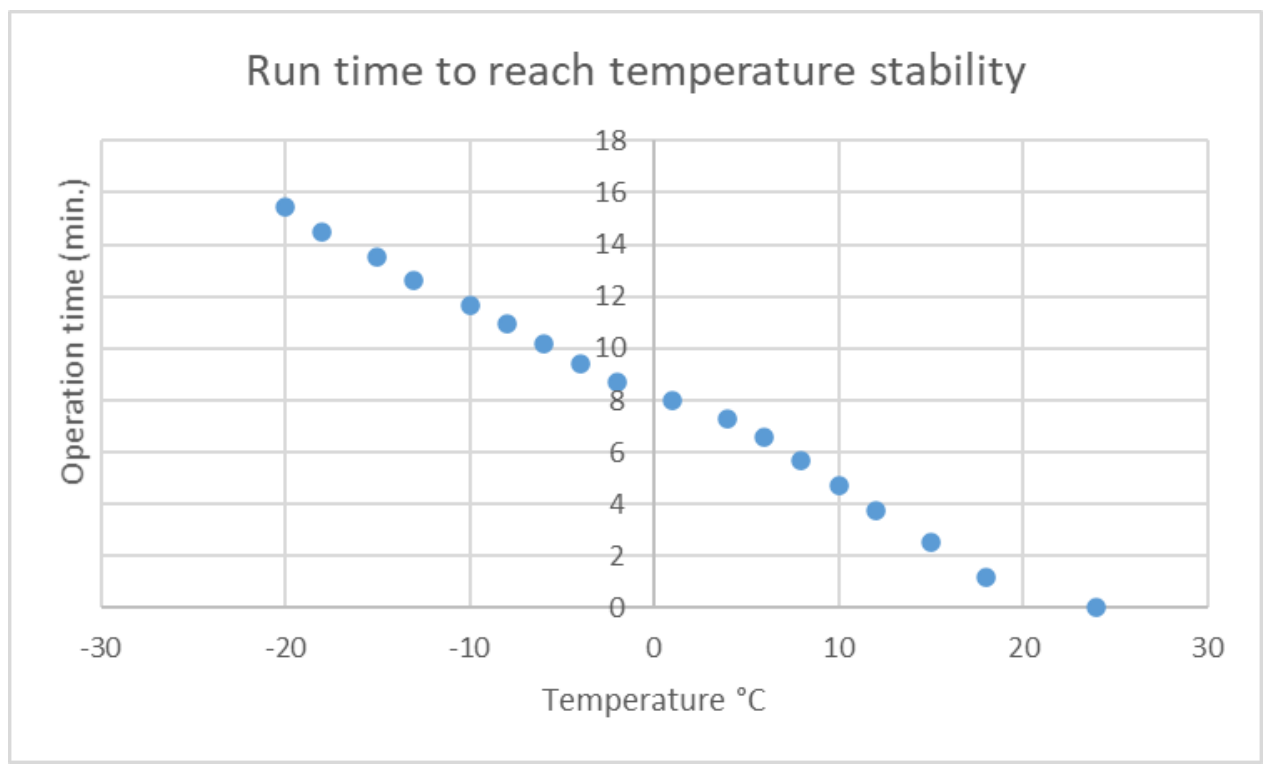

Figure 3. Correlation of temperature with the number of samples taken Source: Research group

Strong negative correlation with -0.9978 data in works at the 18 randomized tests selected in sampling, which means that over time approximately 15.48 minutes for the equipment to reach lower temperatures starting from $25^{\circ} \mathrm{C}$ (room temperature) to $-20{ }^{\circ} \mathrm{C}$ inside. Figure 4 shows the correlation between operating time and temperature reached.

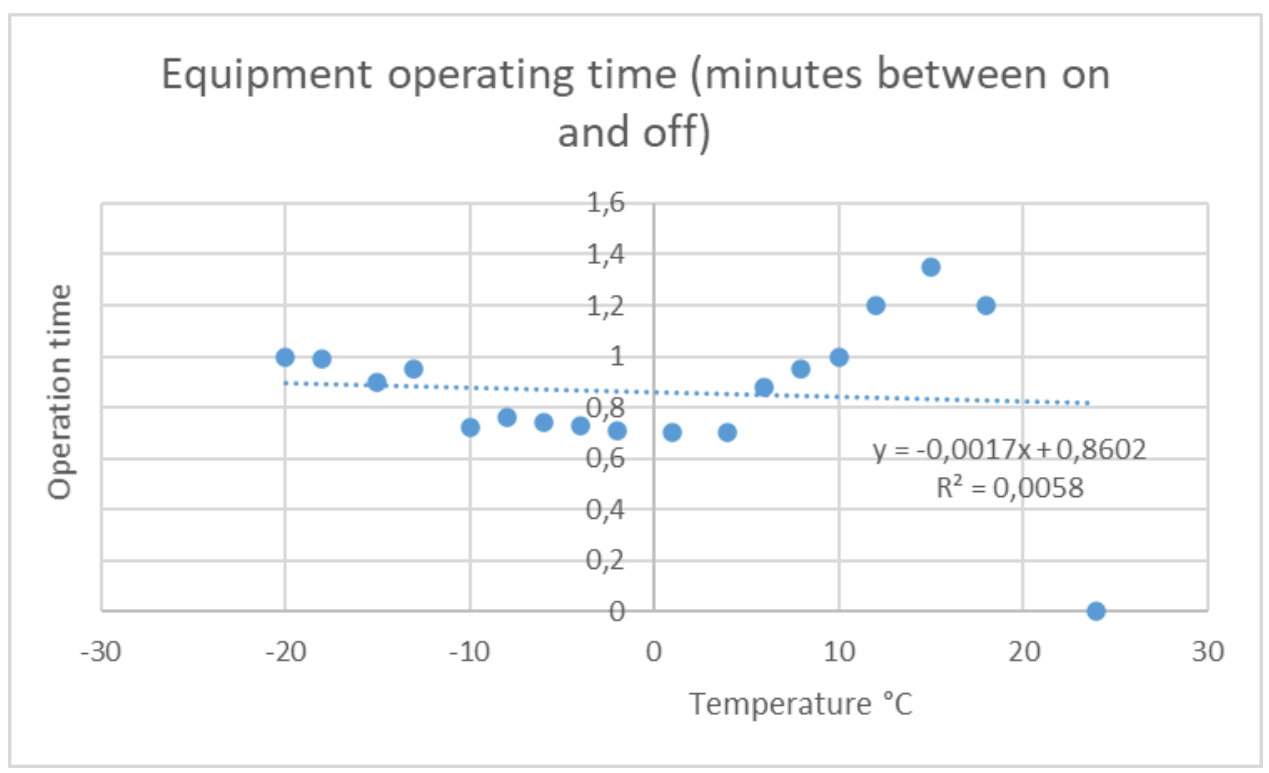

Figura 4. Correlación de tiempo de operación y temperatura alcanzada 
With the very low negative correlation with -0.07612 , it can be seen that there are no specific times between stop and start of the equipment to obtain indicated temperatures, its assessment is based on variables such as capacity volume and external environmental conditions. Figure 5 shows the graph of the equipment humidity correlation as a function of the internal chamber temperature.

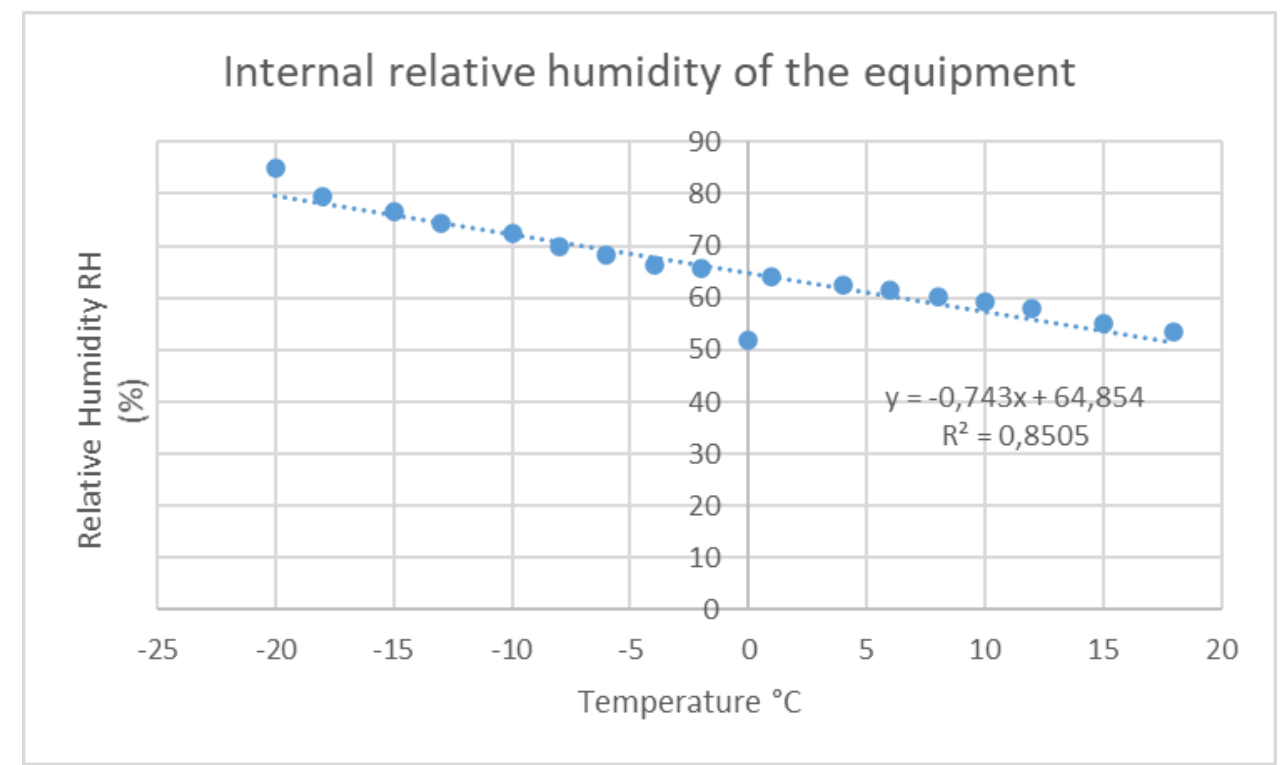

Figure 5. Equipment humidity correlation as a function of the internal chamber temperature

The strongly negative correlation -0.9836 , can be seen in the graph that the relative humidity is closely proportional to the temperatures generated, the higher the temperature, the lower the humidity and if there is a lower temperature inside the system, the higher the relative humidity; taking as a condition that the equipment always works without a dehumidifier, that is, in a standard atmosphere at sea level. As a result of the experimentation, in liquid products there is a presence of freezing in approximately $20 \mathrm{~min}$, from the first phase of on and off the compressor, reaching the average internal chamber temperature of $-8.53^{\circ} \mathrm{C}$, with its standard deviation of $4.67^{\circ} \mathrm{C}$., likewise registers an average liquid product temperature of $-0.5^{\circ} \mathrm{C}$ and its standard deviation of $1.03^{\circ} \mathrm{C}$.

Contrasting the results with those of (Eduard et al., 2010) who analyzed several samples of breast milk at a temperature of $-20^{\circ} \mathrm{C}$ in terms of their protein quality and storage time, it was possible to reach 90 days preserving its properties. In products such as vegetables, the conservation begins in approximately $20 \mathrm{~min}$, from the first phase of switching the compressor on and off, reaching the internal temperature of the chamber of $-7.8^{\circ} \mathrm{C}$ with its standard deviation of $3.18^{\circ} \mathrm{C}$. It also records a temperature. vegetable product average of $3.5^{\circ} \mathrm{C}$ and its standard deviation of $1.95^{\circ} \mathrm{C}$. In a study by (García \& Pacheco, 2007) two morphotypes of celery, yellow and white, were stored at a temperature of $10^{\circ} \mathrm{C}$, obtaining results of non-susceptibility to cold, maintaining the physical characteristics for 5 days with average weight losses of $13.73 \mathrm{~g}$ water / $100 \mathrm{~g}$ in white celery and $17.65 \mathrm{~g}$ water / $100 \mathrm{~g}$ in yellow.

In meat/fish products, preservation occurs in approximately $40 \mathrm{~min}$, starting from the first phase of turning the compressor on and off, reaching the internal chamber temperature of $-6^{\circ} \mathrm{C}$ with its standard deviation of $2.68^{\circ} \mathrm{C}$. It also records an average meat/fish product temperature of $0.22^{\circ} \mathrm{C}$ and its standard deviation of $3.21^{\circ} \mathrm{C}$. In the study by (Rota \& González, 2006) samples of flying fish were stored in a domestic type chamber at $-18^{\circ} \mathrm{C}$ for ninety-five days, an estimated shelf life according to previous tests carried out by the crew of the boat that supplied the fish. On the other hand, even though the final product was frozen twice, once on the high seas and the other under the modality of fillets in trays, no signs of deterioration were observed, since rapid freezing methods were used in both processes. Furthermore, defrosting before filleting was carried out at a low temperature $\left(-18^{\circ} \mathrm{C}\right)$, to avoid excessive dripping

\section{Conclusion}

A refrigeration chamber was built that serves a great variety of canned processes for industries, medicine, and domestic service, of importance within the socio-productive sector. A photovoltaic system was used for lighting 
inside the chamber and achieving the sustainability of the cooling system, improving energy efficiency and reducing the environmental pollution.

\section{Acknowledgments}

Special thanks to the workgroup and the authors who, with few resources, were able to satisfy the refrigeration needs of seafood and agricultural products.

\section{References}

Bravo, D., González, F., \& González, J. (2018). Solar cooling of buildings. A state of the art. Construction Engineering Magazine, 33 (2), 115-126.

Cho, K., \& Tae, S. J. (2001). Condensation heat transfer for R-22 and R-407C refrigerant-oil mixtures in a microfin tube with a U-bend. International Journal of Heat and Mass Transfer,44(11), 2043-2051. https://doi.org/10.1016/S0017-9310(00)00253-2

Eduard, M., Sequera, S., Sánchez, D., Henríquez, AB, Romero, M., \& Vizcarra, M. (2010). Variations in the protein composition of mature human milk during frozen storage. Pediatrics (Asunción): Official Organ of the Paraguayan Pediatric Society, 37 (3), 187-194.

El Mays, A., Ammar, R., Hawa, M., Abou Akroush, M., Hachem, F., Khaled, M., \& Ramadan, M. (2017). Improving photovoltaic panel using finned plate of aluminum. Energy Procedia, 119, 812-817. https://doi.org/10.1016/j.egypro.2017.07.103

FAO. (2017). Perpectiva mundial del atun. Información y Análisis sobre el Comercio Mundial de Pescado.

Farfán, R. F. M., Zambrano, T. Y. M., Badillo, F. R. A., \& Solís, A. A. H. (2020). Design and Construction of an Industrial Ship Conditioning System. International Journal of Physical Sciences and Engineering, 4(1), 29-38.

Gámez, MR, Pérez, AV, \& Álava, LAC (2019). University work as a guarantee of sustainable development. Practical experiences. EDUCARE-UPEL-IPB-Second New Stage 2.0 Magazine, 23 (2), 56-76.

García, A., \& Pacheco-Delahaye, E. (2007). Efecto de la temperatura sobre la calidad postcosecha del apio criollo. Agronomía Tropical, 57(4), 323-330.

Gónzalez de la Cruz, R., \& Gónzalez, R. (2006). Metodología para la evaluación de sistemas de refrigeración industrial. Scientia Et Technica, $\operatorname{XII}(30), 215-217$.

Gooding, J., Edwards, H., Giesekam, J., \& Crook, R. (2013). Solar City Indicator: A methodology to predict city level PV installed capacity by combining physical capacity and socio-economic factors. Solar Energy, 95, 325335. https://doi.org/10.1016/j.solener.2013.06.027

Logicbus. (2020). www.logicbus.com.mx.

Ministerio de Acuacultura y Pesca. (2014). En Manta: Países del Océano Pacífico Oriental analizan el estado poblacional del dorado. BOLETÍN N ${ }^{\circ}$ 092/VAP.

Nižetić, S., Čoko, D., Yadav, A., \& Grubišić-Čabo, F. (2016). Water spray cooling technique applied on a photovoltaic panel: The performance response. Energy conversion and management, 108, 287-296. https://doi.org/10.1016/j.enconman.2015.10.079

Oh, H. K., \& Son, C. H. (2011). Condensation heat transfer characteristics of R-22, R-134a and R-410A in a single circular microtube. Experimental thermal and fluid science, 35(4), 706-716. https://doi.org/10.1016/j.expthermflusci.2011.01.005

Pérez, AV, Araus, WMS, Viteri, CGV, \& Gámez, MR (2020). A model for sustainable energy development. The university, geography and endogenous resources / A model for sustainable energy development. The university, geography and endogenous resources. Venezuelan Geographical Magazine, 61 (1), 220-234.

Quinto, P., Carvajal, I., Sánchez, F., \& Abugaber, J. (2005). Evaluation of a refrigeration system using endoreversible thermodynamics. Technological information, 16 (5), 49-55.

Real Pérez, G. L. (2017). Seguridad, Ambiente y Fuentes Renovadles de Energía. Ecuador: Editorial Mar Abierto.

Rehman, S., Ahmed, M. A., Mohamed, M. H., \& Al-Sulaiman, F. A. (2017). Feasibility study of the grid connected 10 MW installed capacity PV power plants in Saudi Arabia. Renewable and Sustainable Energy Reviews, 80, 319-329. https://doi.org/10.1016/j.rser.2017.05.218

Rodríguez, M., \& Vázquez, A. (2018). La Energía Fotovoltaica en la Provincia de Manabí (Ediciones UTM ed.).

Rota, MMI, \& González, GDVR (2006). Effect Of Storage Time At $-18^{\circ} \mathrm{C}$ On The Bacteriological And PhysicalChemical Characteristics Of Flyingfish Fillets (Dactylopterus volitans). Scientific Journal, 16 (2), 195-201. 
Solares, L. c. (2021). https://casasolar.online/. Retrieved from Evaluación de un Sistema de Refrigeración usando la Termodinámica Endorreversible

Syrek, K., Sennik-Kubiec, A., Rodríguez-López, J., Rutkowska, M., Żmudzki, P., Hnida-Gut, K. E., ... \& Sulka, G. D. (2020). Reactive and morphological trends on porous anodic $\mathrm{TiO} 2$ substrates obtained at different annealing temperatures. International Journal of Hydrogen Energy, 45(7), 4376-4389.

TURCK. (2020). TURCK.COM. 